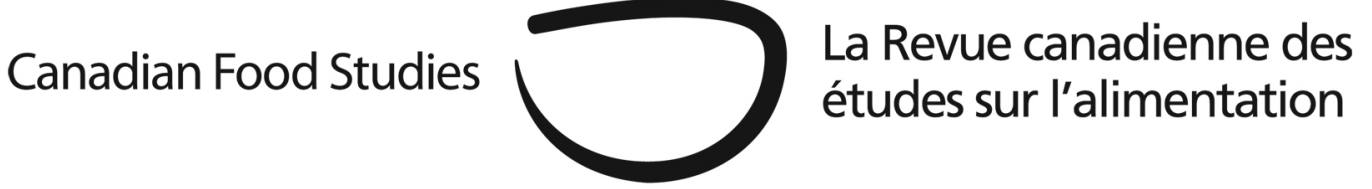

\title{
Digital Work
}

\section{Reflections on "As we fish and farm," a radio documentary}

\author{
Kristen Lowitt
}

Department of Natural Resource Sciences, McGill University, klowitt@mun.ca

Four years ago, I made my first trip to Bonne Bay, a remote fjord on Newfoundland's west coast, to begin my doctoral research at Memorial University about the local food and fishing system around Bonne Bay. The region of Bonne Bay has a population of about 3,000 people, situated in five communities along the north and south sides of the bay (see Fig. 1). Traditionally, the food system was based on a system of "occupational pluralism" in which residents provided for themselves as much food as they could through fishing for sale and subsistence and through home gardening (Ommer et al. 2007, 118). As Cadigan (2002) described, "the inshore fishery dictated that settlements were scattered along the rugged coastline, but gardens were just as important features of communities as were flakes, stages, and ships" (250).

However, the food system around Bonne Bay has changed significantly over the past number of decades. The shift to a cash-based economy, the transition to wage labour in processing plants (instead of home-based fish processing), and the construction of new roads providing access to grocery stores, all led to changes in the local food system. Like many other 
coastal communities throughout Newfoundland and Labrador, change in the Bonne Bay region has been particularly rapid since the early 1990s, when cod and other groundfish stocks were placed under moratoria. The collapse of cod stocks led to one of the largest industrial layoffs in Canadian history (Bavington 2010).

Today, while the fishing industry continues to be restructured, cod stocks have not been rebuilt, the number of fish harvesters and small processing plants are declining, and communities around Bonne Bay face high rates of out-migration, particularly among young people (Fisheries and Oceans Canada 2012; MacDonald et al. 2013; Walsh 2011). There has been a shift to shellfish harvesting and processing following the collapse of groundfisheries. Nonetheless, value from shellfisheries has not fully compensated for the lost income from groundfisheries, particularly for small-scale fish harvesters and processors (Ommer and the Coasts Under Stress Research Team 2007; Schrank 2005). Tourism has also assumed a more important role in the local economy, and many households-including those that fish-rely on seasonal tourism employment. Finally, a growing but undocumented number of local residents migrate for work elsewhere (MacDonald et al. 2013).

In this context my doctoral research sought to understand the implications of these changes for the food security of coastal communities around Bonne Bay. One of the ways I tried to capture the story of a changing food and fishing system was in the form of a short radio documentary. Entitled “As we fish and farm," the documentary features three individuals describing their challenges and hopes in fishing and farming around Bonne Bay today. I produced "As we fish and farm" during a radio documentary-making workshop in November 2012. The workshop was led by Chris Brookes, award-winning radio documentary producer, ${ }^{1}$ and organized by the Community-University Research for Recovery Alliance (CURRA) at Memorial University. ${ }^{2}$ I was one of a group of about ten participants that took part in the radio documentary workshop as a way of sharing results from the CURRA project with researchers, community partners, and the Bonne Bay community. The Voice of Bonne Bay (VOBB), ${ }^{3}$ a small, volunteer-run community radio station that broadcasts throughout the Bonne Bay region and online, promoted and aired the documentaries developed in the workshop. For me, as an emerging scholar interested in community-based research, the radio documentary offered a creative venue for sharing my research. While I was already well into writing my doctoral dissertation at the time I started the documentary, putting the documentary together made me think more clearly about the main story my research told and reflect on its significance not only for an academic audience but for the people living in the region.

As you listen to "As we fish and farm” you will hear from three individuals whose stories are indicative of many others in the region who fish and farm: Ernie Decker, Marsha Crocker, and Mancel Halfyard. Ernie (see Image 1) has fished for nearly forty years out of Baker's Brook, just north of Rocky Harbour. This is the same place from which his father fished before him and from which his brother also currently fishes.

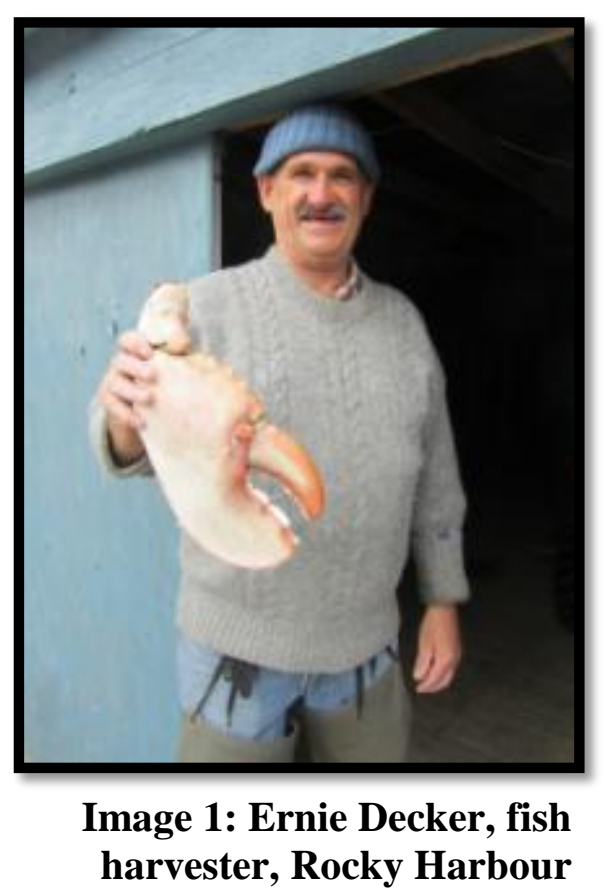




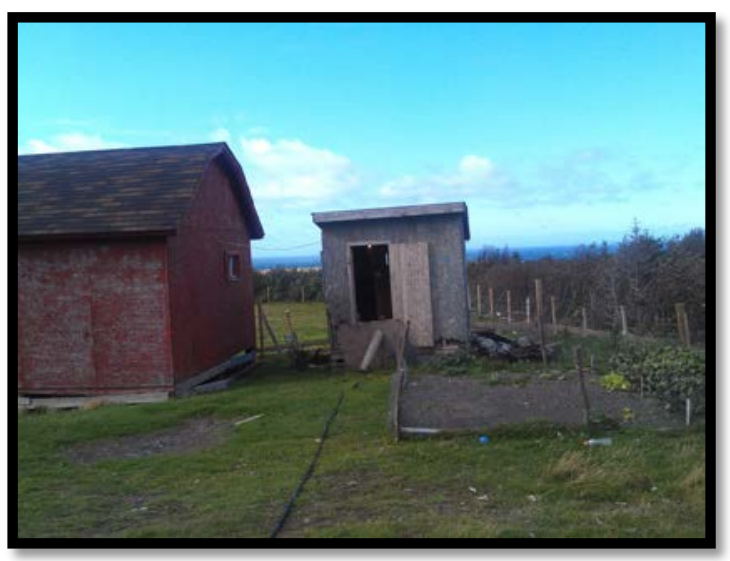

Marsha (see Image 2) lives with her husband and two young sons in Trout River, where she raises animals and fishes commercially with her husband.

Mancel (see Image 3) is nearly 90 years old and continues to garden the same plot of land he has been tending for over fifty years in Woody Point. He has among the largest and most productive gardens around Bonne Bay.

Image 2: Marsha Crocker's gardens, Trout River

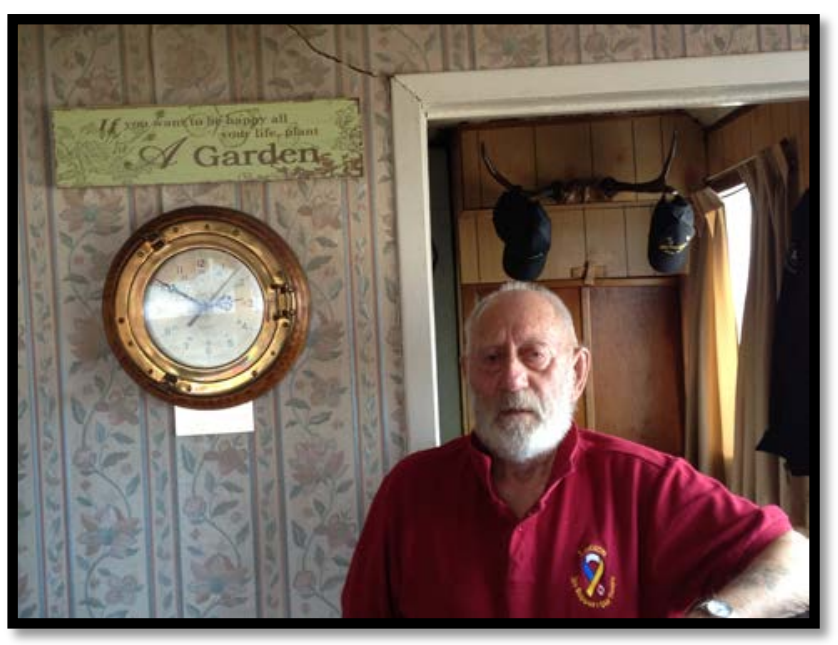

\section{Image 3: Mancel Halfyard, gardener, Woody Point}

\section{References}

Bavington, D. (2010). Managed annihilation: An unnatural history of the Newfoundland cod collapse. Toronto: UBC Press.

Cadigan, S. (2002). “The role of agriculture in outport self-sufficiency.” In R. Ommer (Ed.), The resilient outport (241-262). St. John’s: ISER Books.

Fisheries and Oceans Canada. (2012). Assessment of cod in the Northern Gulf of St Lawrence in 2011. Canadian Science Advisory Secretariat. Science Advisory Report 2012/005. http://www.dfo-mpo.gc.ca/csas-sccs/Publications/SAR-AS/2012/2012_005-eng.pdf 
Ommer, R., Turner, N., MacDonald, M., \& Sinclair, P. (2007). Food security and the informal economy. In C. Parrish, N. Turner, \& S. Solberg (Eds.), Resetting the kitchen table (115-128). New York: Nova Science Publishers.

MacDonald, M., Sinclair, P. \& Walsh, D. (2013). “Globalization, fisheries and recovery.” Community-University Research for Recovery Alliance, Memorial University. Retrieved online http://www.curra.ca/reports.htm

Ommer, R. and the Coasts Under Stress research team. (2007). Coasts under stress: Restructuring and social-ecological health. Kingston: McGill-Queen's University Press.

Schrank, W. (2005). “The Newfoundland fishery: Ten years after the moratorium.” Marine Policy, 29, 407-420.

Walsh, D. (2011). “What restructuring? Who’s rationalization? Newfoundland and Labrador's Memorandum of Understanding on its fishing industry.” In R. Chuenpagdee (Ed.), Contemporary visions for world small-scale fisheries (81- 100). Delft, Netherlands: Eburon Academic Publishers.

1 See www.batteryradio.com

2 See www.curra.ca

${ }^{3}$ See www.vobb.org 